\title{
EFL LEARNERS' BELIEFS AND PRACTICES ON INFORMAL DIGITAL LEARNING OF ENGLISH BEYOND CLASSROOM
}

\author{
Arif Nugroho*, Yunika Triana \\ UIN Raden Mas Said Surakarta, Indonesia \\ (arif.nugroho@iain-surakarta.ac.id)
}

Received: $23^{\text {th }}$ February 2021; Revised: $29^{\text {th }}$ May 2021; Accepted: $27^{\text {th }}$ December 2021

\begin{abstract}
The present-day English language learning is characterized by educational potentials of digital technology for informal learning context. However, research examining EFL learners' characteristics on self-directed use of digital devices for language learning remains a paucity of evidence. Addressing this current issue, the present study aims to shed some light on English language learners' beliefs and practices on informal digital learning of English beyond classroom. A total of 117 Indonesian EFL learners participated in this study through a 5point Likert-scale survey and semi-structured interview. The results revealed the disparity between the EFL learners' beliefs and practices on informal digital learning of English. These EFL learners surely believed that informal digital learning activities could significantly enhance the target language skills, but they slightly engaged in digital learning activities beyond the classroom schedule. The results of semi-structured interviews further delineated that use of native languages in their social circle relationships and limitations of the digital devices used became particular reasons for this circumstance. The results contribute to the realm of English language teaching to reach the possible synchronicity between teacher-designed in-class and out-class digital learning activities and students' language learning styles and preferences to achieve the success of target language learning.
\end{abstract}

Key Words: autonomous learning; informal digital learning of english; learners' beliefs; learners' practices

\section{ABSTRAK}

Pembelajaran bahasa Inggris masa kini bercirikan potensi pendidikan teknologi digital untuk konteks pembelajaran informal. Namun, penelitian yang meneliti karakteristik pelajar EFL tentang penggunaan perangkat digital secara mandiri untuk pembelajaran bahasa masih tetap kekurangan bukti. Mengatasi masalah saat ini, penelitian ini bertujuan untuk menjelaskan keyakinan dan praktik pembelajar bahasa Inggris tentang pembelajaran digital informal bahasa Inggris di luar kelas. Sebanyak 117 pelajar EFL Indonesia berpartisipasi dalam penelitian ini melalui survei skala Likert 5 poin dan wawancara semi terstruktur. Hasilnya mengungkapkan perbedaan antara keyakinan dan praktik pelajar EFL pada pembelajaran digital informal bahasa Inggris. Pembelajar EFL ini pasti percaya bahwa kegiatan pembelajaran digital informal dapat secara signifikan meningkatkan keterampilan bahasa target, tetapi mereka sedikit terlibat dalam kegiatan pembelajaran digital di luar jadwal kelas. Hasil wawancara semi-terstruktur lebih lanjut menggambarkan bahwa penggunaan bahasa asli dari hubungan lingkaran sosial mereka dan keterbatasan perangkat digital yang digunakan menjadi alasan khusus untuk keadaan ini. Hasilnya berkontribusi pada ranah pengajaran bahasa Inggris untuk mencapai kemungkinan sinkronisitas antara kegiatan pembelajaran digital di dalam dan di luar kelas yang dirancang guru dan gaya dan preferensi belajar bahasa siswa untuk mencapai keberhasilan pembelajaran bahasa target.

Kata Kunci: belajar mandiri; pembelajaran bahasa inggris digital informal; keyakinan peserta didik; praktik peserta didik

How to Cite: Nugroho, A., \& Triana, Y. (2021). EFL Learners' Beliefs and Practices on Informal Digital Learning of English beyond Classroom. IJEE (Indonesian Journal of English Education), 8(2), $198-212$. doi:10.15408/ijee.v8i2.19843

\section{* Corresponding author}

IJEE (Indonesian Journal of English Education), 8(2), 2021, 198-212

P-ISSN: 2356-1777, E-ISSN: 2443-0390 | DOI: http://doi.org/10.15408/ijee.v8i2.19843

This is an open access article under CC-BY-SA license (https://creativecommons.org/licenses/by-sa/4.0/) 


\section{INTRODUCTION}

The twenty-first century English language teaching witnessed advanced information communication and technology (ICT). The availability and affordances of online resources, digital devices, and social networking sites characterize the present-day teaching and learning of English as a second or foreign language (Klimova, 2019; Salehi \& Salehi, 2012). With this digital environment, fostering the potential use of technology for language learning is highly necessary, particularly for language learners (Lee, 2020; Nugroho \& Atmojo, 2020). Using a range of digital devices, language learners are equipped with ample opportunities to perform autonomous learning and create personalized learning ecologies (Lai et al., 2015). Therefore, promoting learners' autonomy for out-of-class language learning becomes a crucial effort to gain the maximum inputs of language acquisition in this digital era.

Nowadays, ELT scholars have begun to acknowledge how language learners are involved in various language learning activities using digital devices in their daily life (Sundqvist, 2019). Lee (2020) mentions the phenomenon of autonomous learning beyond the formal classroom as informal digital learning of English. It is defined as language learning activities carried out by learners outside the classroom using digital devices such as computers, smartphones, tablets, or laptops (Lee, 2020). In an informal digital learning context, language learners are encountered with a situation where they have to independently select the most convenient digital learning activity to enhance their language skills, both receptive and productive (Lai, Wang, et al., 2016; Webb \& Doman, 2020). Since language learners today are at the center of the digital learning environment; hence, examining their beliefs and practices on informal digital learning of English is crucial as a consistent attempt to develop their language skills and abilities.

Research on learners' perspectives about digital technology for language learning has been conducted for years from various points of view (Dashtestani, 2016; Lai \& Zheng, 2018). Previous studies have revealed the significant contribution of digital technology to the development of learners' English skills in the pedagogical classroom through the use of social networking sites, internet resources, and learning management systems (Alberth et al., 2018; Khalil, 2018; Nugroho \& Rahmawati, 2020; Slim \& Hafedh, 2019). In an informal context, it was shown that language learners gained positive concerns on the 
use of technology for independent learning but had hesitations on the absence of help and supports from teachers (Isbell, 2018; Lee \& Dressman, 2018; Naghdipour, 2017).

Studies have further revealed that language learners preferred using digital devices to practice receptive skills of English (e.g., reading news, listening and watching videos, looking for vocabulary meaning) than to perform productive English skills and build social connectivity (Cole \& Vanderplank, 2016; Zainuddin \& Perera, 2019). Results of previous studies have also shown that English learners positively perceived the involvement of social media to enhance their language competence, such as Instagram (Anggraeni, 2017), Facebook (Islam, 2016), WhatsApp (Ahmed, 2019), and Youtube (Fakhruddin et al., 2020). These results indicate that digital technology plays a significant role in developing language learners' skills in the present-day digital learning environment (Goria et al., 2019; Yurdagül \& Öz, 2018).

Having highlighted the results of previous studies, it is evident that digital technology is a promising pathway to achieve language learning success. Previous research has yielded significant roles of technology and language learners' concerns on digital learning activities. However, research examining English as a foreign language (EFL) learners' beliefs and practices on informal digital learning of English remain a paucity of evidence. As the informal learning context has educational potentials, how EFL learners are involved in a range of digital learning activities beyond the formal classroom.

The present study is at the cutting edge of closing the gap by examining EFL learners' beliefs and practices on the self-directed use of digital devices for language learning. An in-depth delineation of how EFL learners believe and practice informal digital learning of English activities is crucial to reach possible synchronicity between teachers' designed digital learning activities and learners' preferences. Such an understanding contributes fruitful insights for teachers on how to develop technology-based learning activities. The research questions posited in this study are "What are EFL learners' beliefs on informal digital learning of English?" and "How do EFL learners practice digital learning of English beyond the classroom?" The answers to these questions are expected to shed more light on the nature and characteristics of EFL learners' digital learning activities in informal settings. 


\section{METHOD}

\section{Research Design}

This study aims to explore EFL learners' beliefs and practices on informal digital learning of English beyond the formal classroom. To this end, descriptive research was adopted by employing a survey design to depict how EFL learners' view or value out-ofclass language learning activities (Fraenkel \& Wallen, 2009; Willis, 2018). Following the survey, semi-structured interviews were conducted to jump into a more in-depth understanding of the participants' responses in the survey about their beliefs and practices on informal digital learning of English.

\section{Participants}

A total of 117 undergraduate students (83 females and 34 male) in English language teaching and linguistics from several universities in Surakarta, Indonesia, were conveniently recruited for this study. They studied English as a foreign language and were native Indonesian speakers. Their age was between 18 and 23 , and the average age was 19. Most of the participants were juniors $(n=54$; $46.15 \%$ ) followed by sophomores ( $\mathrm{n}=$ $29 ; 24.78 \%)$, seniors $(\mathrm{n}=21 ; 17.94 \%)$, and freshman $(\mathrm{n}=13 ; 11.11 \%)$. Sixtyfive $(55.55 \%)$ of them considered themselves as having beginning proficiency level, Forty-one (35.04\%) in medium proficiency level, and only eleven $(9.40 \%)$ self-rated themselves as of advanced proficiency level.

\section{Instruments and Data Collection}

The primary instrument used in this study was the 5-point Likert-scale survey directed to explore the participants' beliefs and practices on informal digital learning of English. The survey was adapted from Kearney et al's. (2012) pedagogical frameworks of digital learning environment. The survey comprised 16 items and was divided into three parts. The first part sought participants' demographic information. The second part elicited participants' beliefs about informal digital learning of English. The last part dealt with participants' practices on self-directed use of digital devices for language learning beyond the classroom. In addition, semi-structured interviews were administered with 8 participants (namely P1-P8) to add their views, values, and perspectives on digital learning activities in informal settings. The interviews were conducted through video calls for 15-20 minutes per participant and administered in Indonesian and English, depending on the participants' preferences. 


\section{Data Analysis}

To understand the participants' beliefs and practices about informal digital learning of English, statistical analysis in the form of mean (M) and standard deviation (SD) was conducted using SPSS. To ensure the validity and reliability of the instrument, data, and the whole research, one of the researchers, developed the survey items. The other researcher checked the instrument and data to perform content-related evidence (Fraenkel \& Wallen, 2009). The participants' interview responses were independently read, coded, and classified into emerging trends and themes according to the research questions by the first researcher and an inter-rater who is a senior lecturer and earned a Ph.D degree in English language teaching. Stages of discussion on the differences were further conducted to reach a complete agreement and consensus of the final results.

\section{FINDINGS AND DISCUSSION}

This section presents the results of data analyses regarding the two main themes as limited in the research questions, i.e., EFL learners' beliefs and practices on informal digital learning of English beyond the classroom. Interpretation and implication of the results are further highlighted in the discussion. The participants' representative responses of semistructured interviews are quoted to support the delineation of the findings.

\section{Findings}

\section{EFL learners' beliefs on informal digital learning of English}

Concerning the first research question, the survey results about EFL learners' beliefs on informal digital learning of English are presented in Table 1.

Table 1. Learners' beliefs on informal digital learning of English

\begin{tabular}{llll}
\hline No & Items & M & SD \\
\hline 1 & $\begin{array}{l}\text { Informal digital learning gives significant support to my language } \\
\text { development. }\end{array}$ & 4.30 & 0.86 \\
2 & $\begin{array}{l}\text { Informal digital learning allows me to develop my language skills at any } \\
\text { time and any place. }\end{array}$ & 4.10 & 0.91 \\
3 & $\begin{array}{l}\text { Informal digital learning offers me an alternative to practice language skills } \\
\text { beyond the classroom. }\end{array}$ & 3.85 & 0.73 \\
4 & $\begin{array}{l}\text { Informal digital learning helps me perform self-paced and personalized } \\
\text { English learning outside the classroom. }\end{array}$ & 3.60 & 1.04 \\
5 & $\begin{array}{l}\text { The flexibility of informal digital learning enables me to gain maximum } \\
\text { language inputs without time and space limitations. } \\
\text { Informal digital learning assists me in expanding my language learning } \\
\text { experiences. }\end{array}$ & 0.05 & 0.74 \\
\hline
\end{tabular}




\begin{tabular}{llll}
\hline No & Items & M & SD \\
\hline 7 & $\begin{array}{l}\text { Informal language learning allows me to perform learning activities based on } \\
\text { my own interests. }\end{array}$ & 4.15 & 1.07 \\
8 & $\begin{array}{l}\text { Informal digital learning enhances my autonomous and independent } \\
\text { learning of English. }\end{array}$ & & \\
\hline
\end{tabular}

Notes: The value was based on 5 point-Likert scales with 1 (strongly disagree), 2 (disagree), 3 (neutral), 4 (agree), and 5 (strongly agree)

As depicted in Table 1, EFL learners agreed to all item statements in the survey as indicated by the mean scores above 3 (neutral) in all items. The statement of "Informal digital learning gives significant support to my language development" (item 1) received the highest score of 4.30. Although item 5 (The flexibility of informal digital learning enables me to gain maximum language inputs without time and space limitations) had the lowest mean score of 3.25 , it still indicates an agreement from the EFL learners that informal digital learning of English is flexible since it enables them to practice language learning activities in informal settings. It was also found that EFL learners agreed that informal digital learning outside the classroom became an alternative to practice English skills and perform self-paced learning (item 3 and 4). Table 1 further revealed EFL learners' agreement that informal digital learning of English could enhance their autonomous and independent learning, develop their interests, and expand their language experiences across time and spaces beyond the classroom (item 2, 6, 7, and 8).
The survey's results were echoed in the semi-structured interview responses. The interview participants positively perceived that informal digital learning of English could significantly support the development of their language skills at any time and any place. They believed that this flexibility enabled them to perform autonomous learning and gain maximum English skills inputs based on their language activity preferences and interests. Moreover, some participants in semi-structured interviews also believed that informal digital learning of English could expand their language knowledge and acquisition beyond what their teachers taught in the classroom. As some participants in semi-structured interviews said:

"..... and I one hundred percent believe that our digital activities in daily life such as online chatting, reading news, looking for vocabulary meaning, and watching English-content videos contribute to enhancing our English skills" (P7. Int)

"Yes, I surely believe this kind of informal digital learning can improve my 
English skills and knowledge intentionally" (P1. Int)

"Informal learning using digital devices is flexible, and we can perform it at any time and any place we want. This flexibility gives us the opportunity to learn and practice language skills according to our preferences" (P4. Int)

\section{"Although I have learned teaching} materials in campus, informal learning that I do in my leisure time such as chatting and sharing in my social media can improve my
English ability, even though I do not aware of it" (P6. Int)

\section{EFL learners' practices on informal digital learning of English}

Regarding the second research question, the results of the survey about the learners' practices on informal digital learning of English are demonstrated in Table 2.

Table 2. Learners' practices on informal digital learning of English

\begin{tabular}{|c|c|c|c|}
\hline No & Items & $\mathbf{M}$ & SD \\
\hline 1 & $\begin{array}{l}\text { I use digital devices (e.g., laptops, mobile phones, and tablets) to perform } \\
\text { informal English learning activities in my leisure time outside the classroom. } \\
\text { I regularly perform informal digital learning activities in my daily life out of }\end{array}$ & 2.15 & 1.10 \\
\hline 2 & doing my school assignments. & 1.95 & 0.74 \\
\hline 3 & $\begin{array}{l}\text { I often read English news online to gain new information and improve my } \\
\text { reading skills beyond the classroom. }\end{array}$ & 2.65 & 0.87 \\
\hline 3 & I often make use of online dictionaries to look for the particular meaning of & 2.65 & 0.87 \\
\hline 4 & $\begin{array}{l}\text { English words and improve my vocabulary mastery beyond my formal } \\
\text { classroom. }\end{array}$ & 3.15 & 0.91 \\
\hline 5 & $\begin{array}{l}\text { I often watch English videos, movies, or dramas with the aim of enhancing } \\
\text { my language skills beyond my formal classroom. } \\
\text { I often chat with others in English via social media (e.g., Facebook, }\end{array}$ & 2.90 & 1.02 \\
\hline 6 & Instagram, WhatsApp, Line). & 1.75 & 0.84 \\
\hline 7 & $\begin{array}{l}\text { (e.g., personal blogs, social media, Youtube videos, etc.). } \\
\text { I often use technology to connect with both native (e.g., American, British, }\end{array}$ & 2.05 & 1.04 \\
\hline 8 & $\begin{array}{l}\text { Australian) and non-native speakers (Japanese, Chinese, Arabian) of English } \\
\text { all over the world. }\end{array}$ & 1.95 & 0.98 \\
\hline
\end{tabular}

Notes: The value was based on 5 point-Likert scales with 1 (strongly disagree), 2 (disagree), 3 (neutral), 4 (agree), and 5 (strongly agree)

Unlike the results of Table 1, Table 2 demonstrates that EFL learners disagreed with most of the item statements about their practices on informal digital learning of English. The only statement agreed by the learners and reached mean score above 3 (3.15) was item 4 (I often make use of online dictionary to look for particular meaning of English words and improve my vocabulary mastery beyond my formal classroom). It was also found that the participants 
were slightly involved in a range of digital activities in informal settings both to enhance their receptive skills and productive skills (item 3, 5, 6, 7, and 8). In short, Table 2 showed that the participants were acknowledged not to regularly carry out informal learning activities using digital devices beyond the formal classroom (item 1 and 2).

The results of semi-structured interviews confirmed the findings of the survey about EFL learners' practices on informal digital learning of English. The results of survey showed although EFL learners believe that informal digital learning of English could significantly support their language development; however, they slightly practiced digital learning activities beyond the formal classroom. This was a crucial finding, and the researchers tried to investigate this issue through semi-structured interviews. More than half of the interview participants confessed to not performing digital learning activities in the target language because their social circles were in their native Indonesian language. It was also mentioned that sharing posts and ideas in social networking sites in English was considered strange to the existent social circles and could potentially disrupt social relationships. It was further revealed that most of the participants preferred to use a mobile phone. Its limitation, such as small screens and limited internet connections, kept the EFL learners from optimizing the potentials of smartphones for improving their language skills in an informal context. As some participants said:

"Of course, I believe that digital learning beyond the classroom will improve my English, but I am aware that I cannot do it consistently because of some reasons such as most of my friends in social media are using Indonesian and I feel shy if I use English" (P2. Int)

"Hmmmm... I often used my smartphone to carry out digital learning including joining an online class. But I face some constraints such as small screens and limited internet connections" (P8. Int)

"It was tiring to watch videos, read long texts, and listen to songs online using my smartphone because of the small screens, and it was also difficult to concentrate for a long time" (P2. Int)

\section{Discussion}

The present study explored EFL learners' beliefs and practices on informal digital learning of English beyond the classroom and found apparent discrepancies between their beliefs and practices. On the one hand, the EFL learners surely believed that informal digital learning of English could significantly enhance their English skills. However, on the other 
hand, they slightly practiced digital learning activities in informal settings beyond the classroom because of some reasons such as interrupting the social circles, limitations of digital devices, and limited internet connections.

There are several interpretations of these findings. First of all, the findings indicate that EFL learners are positively concerned about digital learning of English in informal settings. These positive perceptions confirm the current research findings that language learners preferably use affordances of digital devices, especially smartphones, to practice language skills flexibly without time and space limitations (Dashtestani, 2016; Lee \& Drajati, 2019; Nugroho \& Atmojo, 2020). This finding further suggests that motivating EFL learners to be involved in informal digital learning of English activities consistently is a promising key to achieving language learning success. Educators can augment the educational potentials of technology by focusing on strengthening teacher-designed activities that suit learners' characteristics and interests (Lai et al., 2015; Lai et al., 2016; Lai \& Zheng, 2018).

Various efforts should be made to foster EFL learners' engagement in informal digital learning of English beyond the classroom, particularly by teachers. Educational mediation and teacher assistance are necessary to enhance learners' awareness and motivation to engage in informal digital learning activities (Ahmed, 2019; Hembrough \& Jordan, 2020; Xodabande, 2018). For instance, teachers can create community programs such as informal social groups of students across social backgrounds and levels of English proficiency. It is to facilitate learners develop their confidence in social communities and practice target language skills in a relatively supportive environment. Moreover, teachers can design a digital classroom environment reflected by the frequent use of online resources such as social media and internet sites to assist classroom learning activities. Previous research studies have depicted that teachers' in-class use of digital technology affected students' selfinitiated use of technology to engage in informal learning outside the classroom (Nugroho \& Mutiaraningrum, 2020; Webb \& Doman, 2020).

Regarding the second research problem, this study demonstrated that EFL learners slightly practiced learning activities using digital technology beyond the classroom. This finding was astonishing since they were fully aware of the educational potentials of informal digital learning activities as depicted in 
the results of the first research problem. The particular reasons for this circumstance are the native language use of their existent social circles and the limitations of digital devices. This finding is similar to the result of the study conducted by Lai and Zheng (2018) that EFL learners tended to avoid using target language because their social circles were in their native languages. Moreover, studies of Güneş and Ortaçtepe (2019), Krishan et al. (2020), and Mutiaraningrum and Nugroho (2020) have acknowledged that the limitations of digital devices became particular reasons for language learners to practice digital learning beyond classroom schedule. This finding is truthfully confirmed by this study's result that small screens and slow internet connections became certain reasons for the EFL learners not to engage in informal digital learning of English activities frequently.

Above all, this study's results have several implications for English language teaching. First, English teachers and educators can use the results of this study to understand how language learners believe and practice informal digital learning of English activities. It becomes a continuous effort for language educators to consistently assist language learners in gaining the target language's paramount inputs (Atmojo \& Nugroho, 2020; Lam et al.,
2018). Previous studies have concluded that the role of teachers in promoting learners' autonomy is crucial (Lyddon, 2016; Zainuddin \& Perera, 2019). Second, the results of this study can be used as a reference for school authorities and policymakers to design a learning policy that is suitable to the characteristics of twenty-first digital learning. It will significantly support English teachers in designing technology-based in-class and out-class learning activities that suit learners' interests and preferences. We have outreached the era of technological advancement, and running away from this digitalization is almost impossible. Therefore, English language teaching stakeholders should see this circumstance as an opportunity rather than an obstacle, and promoting informal digital learning of English activities is a promising way to achieve language learning success.

\section{CONCLUSIONS AND SUGGESTION}

This study aims to shed more light on EFL learners' beliefs and practices on informal digital learning of English. The results demonstrate an apparent disparity between their beliefs and actual practices in the daily digital learning beyond the formal classroom. They believe that informal digital learning of English activities can enhance their language development. 
However, another result of this study shows that their practices on informal digital learning of English activities are not as strong as their beliefs. The particular reasons for this disparity as scrutinized in semi-structured interviews were the native languages' use of their social circle relationships and limitations of digital devices they frequently used. These results provide empirical contribution for ELT stakeholders to reach possible synchronicity between teacherdesigned learning activities and learners' language preferences to achieve the success of language teaching.

Apart from these compelling results, several limitations are acknowledged in this study. First, this study was conducted in English as a foreign language learning by involving more than half of participants who selfrated themselves to have a beginning English proficiency level. The results might be biased and potentially show different findings if the study was conducted in English as a second language context. Moreover, this study was conducted in the Indonesian EFL context. Learners from other sociocultural backgrounds and other countries with different internet facilities might indicate different results. Hence, the authors suggest that future research may conduct a further inquiry on a similar topic by involving more heterogeneous participants across social backgrounds and proficiency levels.

\section{REFERENCES}

Ahmed, S. T. S. (2019). Chat and Learn: Effectiveness of Using WhatsApp as a Pedagogical Tool to Enhance EFL Learners Reading and Writing Skills. International Journal of English Language and Literature Studies, $\quad 8(2), \quad 61-68$. https://doi.org/10.18488/journal .23.2019.82.61.68

Alberth, M., Siam, S, I. K., \& Ino, L. (2018). Social Media as a Conduit for Teacher Professional Development in the Digital Era: Myths, Promises or Realities? Teflin Journal, 29(2), 293-306. https://doi.org/10.15639/teflinjo urnal.v29i2/293-306

Anggraeni, C. W. (2017). Students Perspectives toward the Use of Instagram in Writing Class. English Language and Literature International Conference (ELLiC) Proceedings, 1(0), 68-74. https://jurnal.unimus.ac.id/inde x.php/ELLIC/article/view/2412

Atmojo, A. E. P., \& Nugroho, A. (2020). EFL Classes Must Go Online! Teaching Activities and Challenges during COVID-19 Pandemic in Indonesia. Register Journal, 13(1), 49-76. https://doi.org/10.18326/rgt.v13 i1.49-76 
Cole, J., \& Vanderplank, R. (2016). Comparing Autonomous and Class-based Learners in Brazil: Evidence for the Present-day Advantages of Informal, Out-ofclass Learning. System, 61, 31-42. https://doi.org/10.1016/j.system .2016.07.007

Dashtestani, R. (2016). Moving Bravely towards Mobile Learning: Iranian Students' Use of Mobile Devices for Learning English as a Foreign Language. Computer Assisted Language Learning, 29(4), 815-832. https://doi.org/10.1080/0958822 1.2015.1069360

Fakhruddin, Z., Usman, U., Rahmawati, R., \& Sulvinajayanti, S. (2020). Designing English Listening Materials through YouTube Video Editing: Training for English Teachers of Islamic Junior High Schools, Parepare, South Sulawesi. IJELTAL (Indonesian Journal of English Language Teaching and Applied Linguistics), 4(2), 275-290. http://dx.doi.org/10.21093/ijelta l.v4i2.475

Fraenkel, J. R., \& Wallen, N. E. (2009). The Nature of Qualitative Research. How to Design and Evaluate Research in Education (Seventh Edition). Boston: McGraw-Hill, 420.

Goria, C., Guetta, L., Hughes, N., Reisenleutner, S., Speicher, O., Brick, B., \& Cervi-Wilson, T. (2019). Enhancing Learners' Professional Competence via
Duolingo Classroom. Professional Competencies in Language Learning and Teaching, June, 19-29. https://doi.org/10.14705/rpnet.2 019.34.911

Güneş, Ç., \& Ortaçtepe, D. (2019). Conceptual Socialization in EFL Contexts: A Case Study on Turkish EFL Learners' Request Speech Acts Realization. Dil ve Dilbilimi Çalışmaları Dergisi, 15(1), 376-399. https://doi.org/10.17263/jlls.547 766

Hembrough, T., \& Jordan, J. (2020). Creating a Digital Writing Classroom: A Mixed Methods Study about a First-year Composition Tablet Initiative. International Journal of Instruction, 13(2), 567-586. https://doi.org/10.29333/iji.2020. $13239 a$

Isbell, D. R. (2018). Online Informal Language Learning: Insights from a Korean Learning Community. Language Learning \& Technology, 22(3), 82-102. http://hdl.handle.net/10125/446 58

Islam, N. N. (2016). Using Facebook in and Outside of Classroom for Language Education in Rural Areas of Bangladesh: Prospects and Challenges. Society $\mathcal{E}$ Change, $X(4), 22-31$. 
Kearney, M., Schuck, S., Burden, K., \& Aubusson, P. (2012). Viewing Mobile Learning from a Pedagogical Perspective. Research in Learning Technology, 20(1). https://doi.org/10.3402/rlt.v20i0 .14406

Khalil, Z. M. (2018). EFL Students' Perceptions towards Using Google Docs and Google Classroom as Online Collaborative Tools in Learning Grammar. Applied Linguistics Research Journal, 2(2), 33-48. 10.14744/alrj.2018.47955

Klimova, B. (2019). Impact of Mobile Learning on Students' Achievement Results. Education Sciences, $9(2), \quad 90$. https://doi.org/10.3390/educsci9 020090

Krishan, I. A., Ching, H. S., Ramalingam, S., Maruthai, E., Kandasamy, P., Mello, G. De, Munian, S., \& Ling, W. W. (2020). Challenges of Learning English in 21st Century: Online vs. Traditional During Covid-19. Malaysian Journal of Social Sciences and Humanities (MJSSH), 5(9), 115.

https://doi.org/10.47405/mjssh. v5i9.494

Lai, C., Shum, M., \& Tian, Y. (2016). Enhancing Learners' Self-directed Use of Technology for Language Learning: the Effectiveness of an Online Training Platform. Computer Assisted Language Learning, 29(1), 40-60. https://doi.org/10.1080/0958822 1.2014.889714

Lai, C., Wang, Q., Li, X., \& Hu, X. (2016). The Influence of Individual Espoused Cultural Values on Self-Directed Use of Technology for Language Learning beyond the Classroom. Computers in Human Behavior, 62, 676-688.

https://doi.org/10.1016/j.chb.201 6.04 .039

Lai, C., \& Zheng, D. (2018). SelfDirected Use of Mobile Devices for Language Learning beyond the Classroom. ReCALL, 30(3), 299-318.

https://doi.org/10.1017/S095834 4017000258

Lai, C., Zhu, W., \& Gong, G. (2015). Understanding the Quality of Out-of-class English Learning. TESOL Quarterly, 49(2), 278-308.

Lam, Y. W., Hew, K. F., \& Chiu, K. F. (2018). Improving Argumentative Writing: Effects of a Blended Learning Approach and Gamification. Language Learning $\mathcal{E}$ Technology, 22(1), 97-118.

Lee, J. S. (2020). Informal Digital Learning of English and Strategic Competence for Cross-cultural Communication: Perception of Varieties of English as a Mediator. ReCALL, 32(1), 47-62. https://doi.org/10.1017/S095834 4019000181 
Lee, J. S., \& Drajati, N. A. (2019). Affective Variables And Informal Digital Learning of English: Keys to Willingness to Communicate in a Second Language. Australasian Journal of Educational Technology, 35(5), 168-182. https://doi.org/10.14742/ajet.517 7

Lee, J. S., \& Dressman, M. (2018). When IDLE Hands Make an English Workshop: Informal Digital Learning of English and Language Proficiency. Tesol Quarterly, 52(2), 435-445. https://doi.org/10.1002/tesq.422

Lyddon, P. A. (2016). Mobile-assisted Language Learning and Language Learner Autonomy. In S.

Papadima-Sophocleous, L. Bradley, \& S. Thouësny (Eds), CALL communities and culture short papers from EUROCALL 2016 (pp. 302-306). Researchpublishing.net.

https://doi.org/10.14705/rpnet.2 016.eurocall2016.579

Mutiaraningrum, I., \& Nugroho, A. (2020). Social Construction of Knowledge in Synchronous Textbased Discussion during English Language Learning. Journal on English as a Foreign Language, 10(2), 315-336. https://doi.org/10.23971/jefl.v10 i2.1934
Naghdipour, B. (2017). 'Close your Book and Open your Facebook': A Case for Extending Classroom Collaborative Activities Online. Journal of Asia TEFL, 14(1), 130143.

https://doi.org/10.18823/asiatefl .2017.14.1.9.130

Nugroho, A., \& Mutiaraningrum, I. (2020). EFL Teachers' Beliefs and Practices about Digital Learning of English. Edulite: Journal of English Education, Literature, and Culture, 5(2), 304-321. https://doi.org/ 10.30659/e.5.2.287-303

Nugroho, A., \& Atmojo, A. E. P. (2020). Digital Learning of English beyond Classroom: EFL Learners'Perception and Teaching Activities. JEELS (Journal of English Education and Linguistics Studies), 7(2), 219-243. https://doi.org/ 10.30762/jeels.v7i2.1993

Nugroho, A., \& Rahmawati, A. (2020). "Let'S Write a Caption!": Utilizing Instagram To Enhance ESP Students' Writing Skills. Jurnal Basis, $\quad 7(1)$, 1-12. https://doi.org/10.33884/basisu pb.v7i1.1782

Salehi, H., \& Salehi, Z. (2012). Challenges for Using ICT in Education: Teachers' Insights. International Journal of E-Education, $e$-Business, e-Management and $e$ Learning, 2(1), 40-43. 
Slim, H., \& Hafedh, M. (2019). Social Media Impact on Language Learning for Specific Purposes: A Study in English for Business Administration. Teaching English with Technology, 19(1), 56-71.

Sundqvist, P. (2019). Commercial-offthe-shelf Games in the Digital Wild and L2 Learner Vocabulary. Language Learning \& Technology, 23(1), 87-113.

Webb, M., \& Doman, E. (2020). Impacts of Flipped Classrooms on Learner Attitudes towards TechnologyEnhanced Language Learning. Computer Assisted Language Learning, 33(3), 240-274. https://doi.org/10.1080/0958822 1.2018.1557692

Willis, G. (2018). Cognitive Interviewing in Survey Design: State of the Science and Future Directions. The Palgrave Handbook of Survey Research, October, 103107. 10.1007/978-3-319-54395-6_14
Xodabande, I. (2018). Iranian EFL Learners' Preferences of Different Digital Technologies for Language Learning Beyond the Classroom. International Journal of Education and Literacy Studies, 6(3), 20. https://doi.org/10.7575/aiac.ijels .v.6n.3p.20

Yurdagül, C., \& Öz, S. (2018). Attitude towards Mobile Learning in English Language Education. Education Sciences, 8(3), 142. https://doi.org/10.3390/educsci8 030142

Zainuddin, Z., \& Perera, C. J. (2019). Exploring Students' Competence, Autonomy and Relatedness in the Flipped Classroom Pedagogical Model. Journal of Further and Higher Education, 43(1), 115-126. https://doi.org/10.1080/0309877 X.2017.1356916. 